\title{
A Model of When to Negotiate
}

\section{Citation}

Babcock, Linda, Hannah Riley Bowles, and Julia Bear. "A Model of When to Negotiate." In The Oxford Handbook of Economic Conflict Resolution, edited by Rachel Croson and Gary Bolton, 313-331. New York: Oxford University Press, 2012.

\section{Published Version}

10.1093/oxfordhb/9780199730858.013.0022

\section{Permanent link}

http://nrs.harvard.edu/urn-3:HUL.InstRepos:39146093

\section{Terms of Use}

This article was downloaded from Harvard University's DASH repository, and is made available under the terms and conditions applicable to Other Posted Material, as set forth at http:// nrs.harvard.edu/urn-3:HUL.InstRepos:dash.current.terms-of-use\#LAA

\section{Share Your Story}

The Harvard community has made this article openly available.

Please share how this access benefits you. Submit a story.

Accessibility 


\section{Oxford Handbooks Online}

\section{A Model of When to Negotiate: Why Women Don't Ask a}

Linda Babcock, Hannah Riley Bowles, and Julia Bear

The Oxford Handbook of Economic Conflict Resolution

Edited by Rachel Croson and Gary E. Bolton

Print Publication Date: Sep 2012

Subject: Economics and Finance, Micro, Behavioral, and Neuro-Economics, Economic Theory and Mathematical Models

Online Publication Date: Dec 2012 DOI: 10.1093/oxfordhb/9780199730858.013.0022

\section{Abstract and Keywords}

This article reports a model explaining previously identified gender differences in negotiation and generating new and testable insights. It specifically addresses how prescriptive gender stereotypes affect evaluators' perceptions of an employee who negotiates for higher compensation and how they influence negotiators' subjective experience of asking for higher pay. Immediate salary gains from the negotiation, the long-run reputation costs of negotiating, and the effect of negotiating on one's self-image may help to explain why it might be rational for women to be more reticent than men about bargaining for higher pay. The reputation costs of negotiating may depend on the norms in the local environment. Decreased status in the workplace constrains men's propensity to negotiate. The two-period model articulates the conditions necessary for increasing the likelihood that women will negotiate and suggests that finding mechanisms such as focal points or "calls to action" can help women to coordinate around negotiating.

Keywords: gender differences, negotiation, gender stereotypes, evaluators, compensation, bargaining, reputation costs, two-period model

Gender differences in bargaining behavior have long been observed and have been implicated as causes of the glass ceiling, the gender wage gap, and other gender inequalities. Linda Babcock, Julia Bear, and Hannah Riley Bowles provide a model describing the incentives that men and women face in choosing to negotiate for their compensation. They show that this model can predict the observed gender differences in bargaining behavior. The results demonstrate how collective action is necessary in order to equalize the bargaining behavior and outcomes of men and women. 
Linda Babcock is James M. Walton Professor of Economics at the Heinz College of Carnegie Mellon University. She is the founder and faculty director of the Program for Research and Outreach on Gender Equity in Society (PROGRESS) and the coauthor of Women Don't Ask: Negotiation and the Gender Divide. Julia Bear is a postdoctoral scholar in industrial engineering and management at the Technion-Israel Institute of Technology. Her research focuses on gender roles and negotiation behavior. Hannah Riley Bowles is Associate Professor of public policy at the Harvard University's John F. Kennedy School of Government and the faculty director of Women and Power, the Kennedy School's executive program for women leaders from the public, private, and nonprofit sectors. Her work focuses on gender differences in a wide variety of organizational settings.

(p. 314) Research suggests that women are more likely than men to pass over opportunities to negotiate for higher compensation. Studies from the laboratory, surveys, and the field suggest that men are at least four times more likely than women to negotiate for compensation (Babcock and Laschever, 2003; Babcock et al., 2006; Small, Gelfand, Babcock, and Gettman, 2007). When they do negotiate, women tend to claim smaller percentage increases than men on their initial salary offers (Brett and Stroh, 1997; Gerhart and Rynes, 1991; Stevens, Bavetta, and Gist, 1993). Aghast by women's apparent lack of negotiating ability as well as the implications of this "gender negotiation gap" for the gender wage gap, both policy makers and professors have proposed additional training for women to raise their negotiating aspirations and effectiveness.

In this chapter, we argue that this perceived bargaining deficiency on women's part is actually a rational response to the differences in incentives and expectations that men and women face in compensation negotiations-one that is obscured by focusing solely on the immediate material payoffs from negotiation. Gender differences in immediate material payoffs (e.g., wage increases due to the negotiation) are, of course, important. Even small differences in salaries can accumulate into substantial wealth differences as raises are granted on a percentage increase (Babcock and Laschever, 2003). However, compensation negotiations can also affect negotiators' reputations in ways that could have long-term career implications and that could ultimately affect one's future earning potential (e.g., Curhan, Elfenbein, and Kilduff, 2009; O'Connor and Arnold, 2001; Tinsley, O'Connor, and Sullivan, 2002). Finally, it is important to take into account how male and female employees experience the negotiation process and how it affects how they view themselves for having negotiated (Curhan, Elfenbein, and $\mathrm{Xu}, 2006$ ). All of these factorsimmediate salary gains from the negotiation, the long-run reputation costs of negotiating, and the effect of negotiating on one's self-image-may influence the decision to negotiate for higher compensation. These factors also help to explain why it might be rational for women to be more reticent than men about bargaining for higher pay. 


\section{Compensation negotiations are masculine stereotyped}

Gender stereotypes influence our expectations about how men and women typically behave and perform in various situations. For example, there is a descriptive stereotype that men are more competitive and effective negotiators than women (Kray and Thompson, 2005). Gender stereotypes also influence how we think men and women should act in particular situations. For instance, research shows that, in American culture (as well as in many other cultures), we believe that men should be agentic (e.g., take charge, assert their self-interest) and that (p. 315) women should be communal (e.g., defer, care for others). These normative gender-based behavioral expectations are prescriptive stereotypes (or gender roles, Eagly, 1987; for broader theoretical discussions of descriptive and prescriptive gender stereotypes, see Burgess \& Borgida, 1999; Eagly and Carli, 2007; Rudman and Glick, 2008). In this chapter, we focus primarily on how prescriptive gender stereotypes influence evaluators' perceptions of an employee who negotiates for higher compensation and how they influence negotiators' subjective experience of asking for higher pay.

A recent study showed that negotiating for higher compensation is still generally perceived as a stereotypically masculine (and unfeminine) behavior (Bear, 2011). This perception has important implications for how people perceive men and women who negotiate for higher pay and how men and women who negotiate feel about themselves when they ask for higher pay. Extensive research shows that people respond negatively to women when they engage in counterstereotypical behavior in the workplace (for reviews, see Eagly and Carli, 2007; Heilman, 1983; Rudman and Glick, 2008). Because negotiating for greater compensation is counterstereotypical for women and violates prescriptions of the feminine stereotype, women who negotiate for higher pay are penalized socially (Amanatullah and Morris, 2010; Bowles, Babcock, and Lai, 2007). They may also experience personal discomfort from engaging in counterstereotypical behavior (Bosson, Prewitt-Freilino, and Taylor, 2005). One study showed that some individuals will pay to avoid engaging in counterstereotypical activities, even in a lab context with no clear social consequences (Bem and Lenney, 1976). Women may avoid negotiating for higher pay because of the negative consequences of how they will be perceived by others and because of how it will tarnish their feminine self-image.

In this chapter, we elaborate further on the differential influence for men and women of compensation negotiation being a masculine activity. We develop a model of the decision to negotiate that depends on how others respond to the negotiator and on how negotiators feel about themselves for having negotiated. We embed this model in a gametheoretic framework that illustrates how coordination among the negotiators can change the parameters of the decision model and lead to different equilibrium outcomes. This model raises a series of new research questions and suggestions for future research. 


\section{A model of the individual decision to negotiate for higher compensation}

We propose a two-period model in which employees make decisions about whether to negotiate for higher compensation in period 1. Our purpose in creating a mathematical model is to be concrete about the different effects that (p. 316) negotiating may have on a person's utility and then to investigate how optimal decisions are affected by the salience of gendered behavioral norms and expectations within the negotiation context. While we are particularly interested in using the model to understand gender differences in the decision to negotiate, the model is general enough to explore any kind of situation in which stereotype-based expectations create differential incentives for different types of people to negotiate.

We specify the utility function to be wages in time periods 1 and $2\left(W_{1}, W_{2}\right)$ and by intrinsic utility derived from how negotiators feel about themselves for having negotiated in period $1\left(X_{1}\right)$ :

$$
U_{1}=U\left(W_{1}, W_{2}, X_{1}\right)=\alpha W_{1}+\delta \alpha W_{2}+\beta X_{1}
$$

The latter component of utility, $X_{1}$, we call identity, following Akerlof and Kranton (2000). The weighting of parameters $\alpha$ and $\beta$ reflect the importance of wages versus identity in the utility function. The discount factor $(\delta)$ indicates that outcomes in the future are less valuable than outcomes in the present.

Our model captures three different ways in which negotiating influences utility. First, there is the most obvious way studied by numerous negotiation scholars: negotiating for higher compensation can lead to an employer granting that request and paying more. Second, negotiating may impact future earnings if the negotiation process influences how others at work feel about the negotiator and interact with him or her in the future. Third, the subjective experience of the negotiation influences the negotiator's identity. We next discuss each of these three concepts and then integrate them into an overall decision to negotiate.

\section{Will Negotiating Raise My Salary?}

Research indicates that negotiating for higher compensation tends to increase salaries (Gerhart and Rynes, 1991; Pinkley and Northcraft, 2000). We model the value of $W$ in the first period as contingent on whether the employee negotiates and how much the employer changes the salary as a result of the negotiation:

$$
W_{1}=W_{\mathrm{o}}+\gamma_{j} N_{1}
$$


where $N=0$ if the employee does not negotiate and $N=1$ if the employee does negotiate. The amount the employer changes the wage as a result of the negotiation is $\gamma_{j}$, where $\gamma_{j} \geq$ 0 and the subscript indexes the sex of the negotiator ( $m$ for men and $w$ for women) since this parameter may differ for men and women. Some research suggests that negotiating counterparts are likely to offer men more than they offer women (Ayres and Siegelman, 1995; Belliveau, 2005; Solnick, 2001; Solnick and Schweitzer, 1999). Nevertheless, negotiating is likely to have a positive payoff for both men and women, and how negotiators value these instrumental (p. 317) wage outcomes is assessed by $\alpha$ in the utility function. We assume that the negotiated increase also carries into the second period:

$$
W_{2}=W_{1}=W_{0}+\gamma_{j} N_{1}
$$

\section{Will Negotiating Have Reputation Effects that could Undermine My Future Earnings?}

Researchers have demonstrated that evaluators perceive women who negotiate for higher compensation (as compared to those who do not) as less nice and more demanding and, as a result, they are less inclined to work with them (Bowles et al., 2007). This effect persists even when they explain that they have an outside offer for more money (Bowles and Babcock, 2009). Across numerous experiments, researchers have found this cost of negotiating, which we call a reputation cost, to be significantly greater for women than men (Bowles and Babcock, 2010; Bowles et al., 2007). Our research suggests that these reputation costs occur because negotiation for greater pay contradicts the communal prescriptions of the feminine stereotype-whereas it aligns with the agentic character of the masculine stereotype.

In a similar vein, Rudman (1998) found that women who self-promote are considered less likeable and less hireable than modest women. The different interpersonal impressions that women and men make when they behave assertively are important because likeability and social connections in the workplace matter. A recent study found that, for assertive women, evaluators shift the hiring criteria to emphasize social skills more than competence, whereas for assertive men, competence and social skills are given equal weight (Phelan, Moss-Racusin, and Rudman, 2008). Since assertive women are rated as having lower social skills than assertive men, this greater emphasis on social skills when evaluating women has detrimental effects on hiring decisions for assertive women.

Why do reputations have an impact on wages? A reputation represents a belief that the employee's current behavior (e.g., negotiating) will be an indicator of his or her behavior in the future (e.g., being a demanding co-worker). If a woman negotiates and this causes her supervisor and co-workers to believe that she is too demanding, they would reasonably predict that she will behave this way in the future as well. As a result, she may 
be shut out of important social networks, team projects, or interactions with others in the organization.

Research shows that employees' social networks are important to career advancement (Brass, 1984, 1985; Burt, 1992) and increased compensation, in particular (Dreher and Cox, 1996). Some research suggests that social connections may be even more important for women's than men's career achievement (Burt, 1998). Thus, the damage to women's reputation from negotiating has real consequences that may be larger than the effects for men.

(p. 318) Based on this research, we argue that the reputation costs of negotiating should be incorporated into the employee's wages in period 2. As previously depicted, negotiating in the first period may produce a monetary gain if the request is granted $(\gamma)$. This wage increase will carry over into period 2 but will also be affected by how the negotiation affects the negotiator's reputation. The sign and magnitude of this effect will depend on whether it is normative for people of one's "type" (i.e., gender) to negotiate. Counternormative behavior suggests a "lack of fit" within the social environment (Heilman, 1983), which leads to negative impressions that can have negative reputation effects and career implications (e.g., exclusion from career-enhancing social networks, work assignments). These negative career implications can undermine future earnings $\left(W_{2}\right)$ :

$$
W_{2}=W_{1}+\varphi_{j} N_{1}
$$

While negotiating for compensation violates prescriptions of the feminine stereotype in general, it may be the case that whether others punish this behavior is context specific and depends on the norms of the local environment. Therefore, we model the penalty for women as dependent on what other women in the environment do, such that if a woman negotiates and most other women in her environment do not, then $\varphi_{w}<0$ (that is, if (1/I)* $\sum$ $N_{\mathrm{i}} \leq 1 / 2$ then $\varphi_{w}<0$ where $I$ is the number of women in the population of relevance, for example in a firm). If a woman negotiates and most other women do as well, then $\varphi_{w}=0$ (that is, if $\left.(1 / I)^{*} \sum N_{\mathrm{i}}\right\rangle \frac{1}{2}$, then $\varphi_{w}=0$ ) so there are not reputation costs for negotiating (because it is normative). For men, research has suggested that reputation costs are minimal, therefore we assume that $\varphi_{m}=0$ (Bowles et al., 2007). However, if it were counternormative in a particular context for men to negotiate for higher compensation, then $\varphi_{m}<0$. 


\section{Will Negotiating Affect My Identity?}

Research in negotiation has predominantly focused on the immediate instrumental or material outcome of the negotiation. However, recent research has begun to articulate a theory of the subjective outcomes that arise from the negotiation (Thompson, 1990) and develop an empirical strategy for measuring both subjective and instrumental outcomes (Curhan et al., 2006). One subjective outcome to emerge from these analyses is "feelings about the self," which are sometimes an important aspect of how people evaluate their negotiations. ${ }^{1}$ This concept encompasses whether the negotiation positively or negatively impacted the negotiator's self-image or identity (Akerlof \& Kranton, 2000) and whether the negotiation behavior was consistent with the negotiator's own principles and values.

This idea that behavior as well as outcomes impact a person's utility has recently gained considerable traction in economics (Akerlof and Kranton, 2000). (p. 319) Specifically, Akerlof and Kranton (2005) argue that "a person's identity describes gains and losses in utility from behavior that conforms or departs from the norms for particular social categories in particular situations" (p. 12) and that a "person who identifies with being a member of a respective social category then loses utility insofar as her behavior is different from that of the ideal" (p. 13). This notion of identity has been used by economists to understand the way that morality affects decision making (Benabou and Tirole, 2011; Köszegi, 2006; Rabin, 1995), how workers respond to managerial decisions about compensation (Akerlof and Kranton, 2005), and the way that one's behavior provides evidence to oneself about one's identity (Benabou and Tirole, 2004).

Putting these two literatures together, we argue that negotiating may positively reinforce a person's identity if negotiating is consistent with the person's gender identity (i.e., the extent to which the person categorizes him- or herself in stereotypically feminine and/or masculine terms). However, if negotiating conflicts with an individual's gender identity, then the individual may suffer a threat to identity. For instance, Witt and Wood (2010) found conformity to one's gender norms correlates with self-esteem and positive emotions. Negotiating for higher compensation is consistent with the idealized masculine image of the agentic family breadwinner (Callahan-Levy and Messe, 1979; Jackman, 1994; C. L. Ridgeway and Bourg, 2004), so a man's identity may be positively reinforced by initiating a compensation negotiation. For women, on the other hand, making claims to greater pay contradicts cherished images of womanhood as giving rather than taking in nature. Particularly for women who identify with the feminine stereotype, negotiating for higher pay may lead them to have negative feelings about themselves because it contradicts a positive image that they hold of themselves.

One might wonder how these stereotypes with their negative implications for both reputation and identity are so persistent. A partial answer is that stereotypes typically include appealing attributions that stereotyped people themselves embrace. For instance, stereotypes of women as warm and nice help to maintain the system of gender inequality because these represent attractive features that women embrace (Glick and Fiske, 1996, 
2001b). If stereotypes were purely negative, people would be more likely to rebel against them (Glick and Fiske, 1996, 2001b; Kilianski and Rudman, 1998). Therefore, even though prescriptions of the communal stereotypes constrain women's behavior, women embrace them because they feed into positive aspects of their self-identity (Glick and Fiske, 2001a; Jost and Kay, 2005).

For women, the potential immediate material gains from negotiating for higher compensation might not outweigh the personal cost of violating one's idealized feminine self-image. Therefore, even if a woman were negotiating in a context in which no one else would judge her negatively, she might still find the behavior aversive.

In our model, we specify the impact of negotiating on one's identity as:

$$
X_{1}=X_{0}+\theta_{j} N_{1}
$$

(p. 320) where $\theta_{w} \leq 0$ because negotiating may contradict gender identity. Note that the sign of $\theta_{w}$ does not depend on what other women do. ${ }^{2}$ For men, negotiating reinforces their masculine identity, so $\theta_{m} \geq 0$.

\section{The decision to negotiate}

The decision maker will negotiate if:

$$
U\left(W_{1}, W_{2}, X_{1} \mid N_{1}=1\right)>U\left(W_{1}, W_{2}, X_{1} \mid N_{1}=0\right)
$$

or

$$
\alpha W_{o}+\alpha \gamma_{\jmath}+\alpha \delta W_{o}+\alpha \delta \gamma_{\jmath}+\delta \varphi_{\jmath}+\beta X_{o}+\beta \theta_{\jmath}>\alpha W_{o}+\alpha \delta W_{o}+\beta X_{o}
$$

Without loss of generality, we can normalize $\alpha$ to 1 . Therefore, a sufficient (though not necessary as we will see below) condition for the employee to choose to negotiate is:

$$
\gamma_{\jmath}(1+\delta)+\delta \varphi_{\jmath}+\beta \theta_{\jmath}>0
$$

The first term in the equation depicts how wages increase over the two periods because the employer pays more if the employee negotiates than if they do not. The second term represents how having negotiated affects the negotiator's career advancement (and thus future wages) because the negotiation has affected reputation. The third term indicates how negotiating affects the negotiator's identity. ${ }^{3}$

For men, this decision is straightforward because $\varphi_{m}=0$, and all the other terms are positive (or at least non-negative). As a result, negotiation is expected to yield only positive benefits to men because it grants them immediate and long-term wage increases and may positively reinforce their identity. This is an accurate depiction of how the 
decision to negotiate for higher compensation is characterized in the negotiation literature, but it does not accurately represent women's experience.

For women, the calculation is more complicated because some of the terms are positive and some are negative. In the context of a compensation negotiation, previous research suggests that $\gamma_{j}$ is positive (employers respond to negotiation by at least partially granting the request for a wage increase), while the literature on negotiation backlash for women suggests that reputation costs, $\varphi_{j}$, are negative. The parameter, $\theta_{j}$, may be negative because negotiating for more money may conflict with a woman's identity. If the negative consequences of reputation and identity are large enough, they can outweigh the shortterm benefits to negotiating.

While we are mainly focused on compensation negotiations, this model yields insights into negotiating decisions in other domains. In a context such as negotiating something for another person, there may be no negative consequences for (p. 321) a woman. Research indicates that the reputation costs are likely to be zero since behavior that helps another person is consistent with the feminine stereotype (Amanatullah and Morris, 2010). The impact on identity may be positive rather than negative because negotiation for another person reinforces the woman's identity as a helper rather than conflicts with it (Bowles, Babcock, and McGinn, 2005; Bowles, Bear, and Thomason, 2011).

The reputation costs of negotiating may depend on the norms in the local environment, such as the standard practice within the organization and the behavior of the other members of the individual's social category (e.g., whether other women in the organization routinely negotiate). In this case, the sign of $\varphi_{w}$ depends on what other women do and thus creates an interdependence among women's decisions to negotiate. This type of situation has been modeled in the game-theory literature as a coordination game (Bryant, 1983; Van Huyck, Battalio, and Beil, 1990). For simplicity, let us consider a coordination game involving two women. Payoffs from this game are depicted in Table 22.1. ${ }^{4}$

This set-up is called a stag-hunt coordination game and was first conceptualized by the eighteenth-century philosopher Jean-Jacques Rousseau (Crawford, 1991). As depicted in the matrix, if both women choose not to negotiate, the current norm stays in place such that negotiating is a violation of the feminine norm. When a woman does not negotiate she gets a status quo payoff of zero (i.e., she fails to get the additional money from having her request granted, she faces no threat to her identity, and she incurs no reputational costs that could affect her future career and future wages).

If both women choose to negotiate, a new norm is established in which negotiation is acceptable for women. As a result, each woman receives the benefit in both periods from her employer granting her wage request $\gamma_{w}(1+\delta)$, each woman also faces a cost to identity, $\beta \theta_{w}$, but neither woman incurs a reputation cost that undermines her future earnings ( $\varphi_{w}$ drops out because $\varphi_{w}=0$ if $\left.(1 / I)^{*} \sum N_{i}\right\rangle^{1 / 2}$, that is, most women are negotiating so it is no longer counternormative). If one woman chooses to negotiate and one woman does not, the woman who does not negotiate receives neither benefits nor

Page 9 of 22

PRINTED FROM OXFORD HANDBOOKS ONLINE (www.oxfordhandbooks.com). (c) Oxford University Press, 2018. All Rights Reserved. Under the terms of the licence agreement, an individual user may print out a PDF of a single chapter of a title in Oxford Handbooks Online for personal use (for details see Privacy Policy and Legal Notice). 
costs and receives the status quo payoff of zero. However, the woman who negotiates receives the benefits $\left(\gamma_{w}(1+\delta)\right)$ and the costs $\left(\delta \varphi_{w}+\beta \theta_{w}\right)$. The term $\varphi_{w}$ does not drop out since $\varphi_{w}<0$ if $(1 / I) * \sum N_{i} \leq 1 / 2$, that is, most women are not negotiating so a woman's behavior is counternormative and she receives the reputation cost penalty.

\begin{tabular}{|l|l|l|}
\hline Table 22.1 Payoffs to negotiating & \multicolumn{1}{|c|}{ Woman \#2 } \\
\hline Woman \# 1 & Negotiate & Do Not Negotiate \\
\hline Negotiate & $\gamma_{w}(1+\delta)+\beta \theta_{w}, \gamma_{w}(1+\delta)+\beta \theta_{w}$ & $\gamma_{w}(1+\delta)+\delta \varphi_{w}+\beta \theta_{w}$ \\
\hline Do Not Negotiate & $0, \gamma_{w}(1+\delta)+\delta \varphi_{w}+\beta \theta_{w}$ & 0,0 \\
\hline
\end{tabular}

(p. 322) Without knowing more about the values of the parameters, it is not possible to specify which set of strategies are equilibrium strategies and whether or not there are Pareto-efficient outcomes. There are three possibilities for the values of the parameters that will affect which outcomes are equilibria.

\section{Case 1}

Consider the situation in which:

$$
\gamma_{w}(1+\delta)+\beta \theta_{w}<0
$$

In this case, the gain in wages to having the negotiation request granted is not as large (in absolute value) as the negative impact on the woman's identity for having negotiated. As a result, the only Nash equilibrium is that neither woman negotiates because it is a dominant strategy. There is no coordination element to this situation because a woman chooses not to negotiate, no matter what the other woman chooses to do. This arises because the cost to her identity (which is not sensitive to the actions of others) is simply too large to overcome increases in wages.

\section{Case 2}

Consider the situation in which:

$$
\gamma_{w}(1+\delta)+\beta \theta_{w}>0 \text { and } \gamma_{w}(1+\delta)+\delta \varphi_{w}+\beta \theta_{w}<0
$$

The first inequality indicates that the financial benefit to having her wage increase due to negotiation is greater than the cost to her identity for having negotiated. The second inequality indicates that adding in the reputation costs now makes the option to negotiate a negative proposition, where the benefits to negotiation no longer outweigh the costs. In 
this case, there are two Nash equilibria, one in which both women negotiate (because then $\varphi_{w}$ would disappear) and the other in which neither woman negotiates. This now becomes a coordination game in which each woman wants to match the strategy of the other woman. While the "both women negotiate" equilibrium is the Pareto-efficient Nash equilibrium (both women prefer it to the "both women don't negotiate" equilibrium), it entails risk. Each woman would like to move to that equilibrium, but a woman will be worse off if she negotiates and the other woman chooses not to.

\section{Case 3}

Finally, there is a third possibility for the parameter values:

$$
\gamma_{w}(1+\delta)+\beta \theta_{w}>0 \text { and } \gamma_{w}(1+\delta)+\delta \varphi_{w}+\beta \theta_{w}>0
$$

In this case, the only Nash equilibrium is that both women negotiate, because the benefits to negotiation outweigh the costs even when reputation costs arise. This means that each woman will choose to negotiate no matter what the other woman does, so negotiation is a dominant strategy and no coordination problem arises.

\section{(p. 323) Discussion of the Three Cases}

Because the different parameter values in the three cases predict different equilibria, it is important to think about what their likely values are of the parameters for women in a salary negotiation situation (later in the chapter we explore other negotiation contexts that will produce different parameter values and therefore different equilibrium outcomes). The research strongly suggests that while $\gamma_{w}$ is greater than zero, both $\varphi_{w}$ and $\theta_{w}$ are less than zero.

Recall that case 1 implies that a woman would never negotiate, even in situations in which there were no reputation costs, because the identity costs are too large. While this may be true for individual women in particular contexts, in salary negotiations the evidence suggests that the gains to even a single negotiation can be enormous, potentially several hundred thousand dollars when measured over the course of a career (Babcock and Laschever, 2003, 2008). This may make it unlikely that the identity costs are larger than these financial gains.

Case 3 implies that women always negotiate, even in situations in which there are large reputational costs. However, empirical evidence implies that case 3 may be relatively rare because reputation costs for women who negotiate for their salary can be substantial (Bowles and Babcock, 2009; Bowles et al., 2007) and much larger than reputation costs for men, which is consistent with women being much less likely than men to initiate negotiations over salary (Bowles et al., 2007).

It is reasonable to suggest that the case 2 parameter values are the most likely to exist in salary negotiations and, therefore, issues of coordination will be important. However, an 
unanswered question remains: Because this is a coordination game with multiple equilibria, which equilibrium will be most likely to arise and under what conditions?

A large body of research on coordination games with parameters values for case 2 has studied how participants play them in the laboratory. In general, there are three main empirical findings (see Camerer, 2003, for a summary of this research). First, over time, groups of participants converge to one of the two Nash equilibria and do not always choose the Pareto-efficient equilibrium. In a study by Cooper et al. (1989), participants in the two-player stag hunt coordination game gravitated to the Pareto-dominated equilibrium (in our game this is the "both women don't negotiate" equilibrium) in 97 percent of the cases. Second, limited communication between the players can help but does not completely eliminate selection of the inefficient equilibrium. For example, in the Cooper paper when one player could announce her intended choice, the two participants moved to the Pareto-efficient equilibrium only 67 percent of the time. Third, initial conditions or history can help considerably to predict which equilibrium they gravitate toward. For example, if one of the equilibria is the status quo, it creates a focal point for future play, increasing the likelihood that participants will continue to play. In our situation, this means that if the current status quo is the "both women don't negotiate" equilibrium, this creates a strong momentum to continue to play.

\section{(p. 324) Factors that Can Affect Coordination}

While these games are highly stylized and stark abstractions of reality, the lessons from them can help us to understand the complexity involved in changing norms by individuals coordinating their behavior. Although it is clear that all the parties involved could be better off through collective action (together deciding to play the Pareto-efficient Nash equilibrium), the risks involved when individuals make decisions separately are substantial. The empirical evidence also points to the importance of history and focal points that could influence whether or not actions that change the norms could occur.

In practice, what could serve as coordinating mechanisms that would encourage women to choose the risky, yet Pareto-efficient equilibrium? Perhaps legislation such as the passage of the Paycheck Fairness Act that is working its way through Congress could serve as a focal point. This legislation points to the importance of women using negotiation to close the gender salary gap and allocates money to teach women and girls to negotiate. This type of initiative could provide a coordinating mechanism that would encourage women to negotiate and be more confident so that other women would decide to negotiate as well.

Though this legislation is encouraging, applying recent findings from social psychology to the current historical context suggests that it may be difficult to achieve the level of collective action required in order to realize coordinated outcomes. Gender stereotypes are perpetuated because they consist of hostile and benevolent components, and the benevolent components reinforce adherence to the status quo (Glick and Fiske, 2001a; 
Jost and Kay, 2005; C. Ridgeway, 2011). Recent findings from social psychologists have shown that, compared to hostile sexism, benevolent sexism decreases people's likelihood of engaging in collective action for change (Becker and Wright, 2011). More generally, increased contact between dominant and subordinate groups has the ironic effect of undermining interest in collective action among members of the subordinate group (Saguy, Tausch, Dovidio, and Pratto, 2009). In practical terms, this means that the more implicit and benevolent the sexism, the lower the likelihood of collective action to coordinate on the Pareto-efficient Nash equilibrium.

From a historical perspective, this research resonates with societal trends over the last 60 years. The women's rights movement in the 1960s and 1970s in the United States and elsewhere was preceded by outright, hostile sexism. For instance, women could not open their own bank account without a male relative, usually their father or spouse, cosigning on the account. Likewise, discrimination against women in higher education and in the workforce was explicit and accepted. This hostile sexism spurred collective action (i.e., the women's movement) that led to major structural and societal changes. Today, sexism in education and at work is more likely to be implicit and benevolent in nature. For example, the lack of women in positions of power in institutions and high-level career tracks is often explained by women's greater interest in home life as compared to menan interest that is often praised by society. Furthermore, because (p. 325) the decision to negotiate is often thought of as an individual decision, individuals do not recognize the externalities present. In this case, if a woman negotiates, it makes it easier for other women to negotiate-negotiation is unlikely to be seen by women's rights groups as a cause for collective action.

If the coordination problem is a difficult one to solve, it might be more fruitful for those desiring change to focus on how to alter the parameter values of the individual's decision. If negotiation is considered an acceptable and expected behavior, then it is less likely to violate norms for niceness or to be potentially considered asking for too much. For women, this means that the act of negotiating may be less likely to exact reputation and identity costs. While the benevolent stereotypes that inform idealized self-images are slow to change, we cannot forget the drastic transformations that have occurred in women's self-presentation within the past 50 years. Take, for example, a behavior that was once considered revolutionary and unfeminine for women, but is now widely accepted: wearing pants. In 1960, Lois Rabinowitz was ejected from a court in New York for wearing pants, a decision that entailed potential costs to her reputation and her identity. However, as this behavior gradually became acceptable and normative, presumably those costs decreased, and the decision became less risky. Similarly, removing the ambiguity in regard to the appropriateness of negotiation at work may make the decision less risky for women, not only in terms of reputation but also in terms of identity, since norm violation will be less salient.

Though institutionalized forms of collective action may be a remote possibility in the current climate, it is possible to imagine situations in which women's decision calculus could change based on modification of the perceived parameter values, particularly in 
terms of the reputation costs of negotiating. For example, the practice of separating the human resources function (i.e., who does the salary negotiation) and the supervisory function (i.e., who determines assignments and advancement) might serve to minimize the reputation effects for women from negotiating. In addition, companies could make norms about negotiation explicit rather than ambiguous in order to reduce perceived reputation risks (Kray and Gelfand, 2009). Companies could make negotiation an official component of annual performance reviews. Though one might argue that companies have little incentive for adopting such a policy, in the long term, an explicit negotiation policy could benefit corporations in the same way that work-life policies have been shown to be beneficial by increasing employee satisfaction and retention.

\section{Moving beyond salary and gender}

We have used this model to elucidate gender differences among the multiple groups in the propensity to negotiate for higher compensation. However, the model is general enough to help explain differences in the propensity to negotiate across a broad (p. 326) range of situations. For example, this model suggests that the propensity to negotiate is likely to be greater when negotiators face no reputation costs (e.g., anonymous or singleshot interactions). In this case, the decision to negotiate would rest on whether $\gamma_{w}(1+\delta)$ $+\beta \theta_{w}$ was greater than zero, a situation that would arise if the identity cost for having negotiated is not too large and the financial gain for having negotiated is large. This prediction fits with research indicating that gender differences in car purchase prices are diminished when sales occur over the Internet (Scott Morton, Florian, and Silva-Risso, 2003). One explanation for this effect is reduced discrimination, but it is also possible that female negotiators have a greater propensity to negotiate when they know that their gender is not observable and they can avoid others' forming negative impressions of them for having negotiated.

Recent research has shown that decreased status in the workplace also constrains men's propensity to negotiate. Bowles and Al Dabbagh (2011) studied Arab Gulf nationals' propensity to negotiate for higher compensation with global (i.e., multinational) versus local (i.e., national) employers. Male nationals in the Arab Gulf have high status with local employers but low status with global employers. In a simulated employment context, the researchers found that male nationals were significantly more reticent to negotiate for higher pay with global than with national employers.

Other recent research based on interviews with US military and government executives suggests that negotiating for career rewards for oneself (e.g., training, advancement opportunities) is common among government officials but counternormative in military institutions-even though negotiating for career rewards for others is normative in both contexts (Bowles et al., 2011). This scenario fits with case 2 of our model where the status 
quo "do not negotiate" equilibrium is self-perpetuating because of strong norms discouraging such behavior-even in a highly masculine-stereotyped work context.

It is easy to imagine other situations as well, in which negotiating for higher compensation at work would contradict valued aspects of one's identity. For instance, a public-service worker might imagine negotiating for higher compensation as a contradiction of a valued ideal that she or he works to help others and not to make money. Because much of the negotiations literature has focused on compensation negotiations typically in a corporate setting, little is known about the factors that affect the decision to negotiate in settings like public service employment.

\section{Directions for future research}

There is still considerable research to be done. Empirical research should investigate women's propensity to negotiate in settings other than compensation negotiations in which the identity and reputation costs may not be so large. Initial research comparing negotiation over compensation versus work-life issues has shown that women (p. 327) find work-life negotiations less aversive than compensation negotiations whereas the opposite was found for men (Bear, 2011). This may occur because the costs to identity differ for men and women across topics and the impact on the negotiator's reputation may depend on the interaction between the topic and gender of the negotiator.

When norms about negotiation are more explicit, then the identity and reputation costs for having negotiated should be attenuated where negotiation is considered to be appropriate; but this remains an empirical question. It could be that even with explicit norms about negotiation as an acceptable and expected behavior, women still face identity costs due to violating norms for nice, feminine behavior. Likewise, perhaps the penalties to reputation costs for women remain even in the presence of explicit norms about negotiating. Both of these questions could be studied experimentally by manipulating norms about negotiation in various ways and measuring identity and reputation costs, as well as the propensity to negotiate. In addition to investigating the presence versus absence of explicit norms, future research could also examine different types of norms and whether there is a tipping point to change to a different equilibrium. There are many remaining questions that are ripe for future research in this area, particularly how situations affect the parameter values for both men and women and how this affects the decision to negotiate.

\section{Conclusion}


In this chapter, we analyzed the decision to negotiate by explicitly modeling dynamics not typically considered in the existing literature. We parameterized how identity can affect the decision to negotiate, as suggested by Curhan et al. (2006) and considered the impact of negotiating on one's reputation as studied by Bowles et al. (2007). We embedded these factors in a coordination game to highlight the fact that reputation costs may depend on the norms of the situation that are influenced by what other women do. Our model articulates the conditions necessary for increasing the likelihood that women will negotiate and suggests that finding mechanisms such as focal points or "calls to action" can help women to coordinate around negotiating. It also makes predictions about the types of situations that will change women's propensity to negotiate, such as norms in the environment and whether or not interactions are ongoing and have the potential to produce reputation costs.

\section{References}

Akerlof, G. A., \& Kranton, R. E. (2000). Economics and identity. Quarterly Journal of Economics, 115(3), 715-753. doi: 10.1162/003355300554881

Akerlof, G. A., \& Kranton, R. E. (2005). Identity and the economics of organizations. Journal of Economic Perspectives, 19(1), 9-32.

Amanatullah, E. T., \& Morris, M. W. (2010). Negotiating gender roles: gender differences in assertive negotiating are mediated by women's fear of backlash and attenuated when negotiating on behalf of others. Journal of Personality and Social Psychology, 98(2), 256267.

Ayres, I., \& Siegelman, P. (1995). Race and gender discrimination in bargaining for a new car. American Economic Review, 85(3), 304-321.

Babcock, L., Gelfand, M., Small, D., \& Stayn, H. (2006). Gender differences in the propensity to initiate negotiations. In D. D. Cremer, M. Zeelenberg, \& J. K. Murnighan (eds.), Social Psychology and Economics, 239-262). Mahwah, NJ: Lawrence Erlbaum.

Babcock, L., \& Laschever, S. (2003). Women Don't Ask. Princeton, NJ: Princeton University Press.

- - - (2008). Ask for It. New York: Bantam Books.

Bear, J. (2011). "Passing the buck": incongruence between gender role and topic leads to avoidance of negotiation. Negotiation and Conflict Management Research, 4(1), 47-72.

Becker, J. C., \& Wright, S. C. (2011). Yet another dark side of chivalry: benevolent sexism undermines and hostile sexism motivates collective action for social change. Journal of Personality and Social Psychology, 101(1), 62-77. 
Belliveau, M. A. (2005). Blind ambition? the effects of social networks and institutional sex composition on the job search outcomes of elite coeducational and women's college graduates. Organization Science, 16(2), 134-141.

Bem, S. L., \& Lenney, E. (1976). Sex typing and the avoidance of cross-sex behavior. Journal of Personality and Social Psychology, 33(1), 48-54.

Benabou, R., \& Tirole, J. (2004). Willpower and personal rules. Journal of Political Economy, 112(4), 848-886.

(p. 329) Benabou, R., \& Tirole, J. (2011). Identity, morals, and taboos: beliefs as assets. Quarterly Journal of Economics, 126, 805-855.

Bosson, J. K., Prewitt-Freilino, J. L., \& Taylor, J. N. (2005). Role rigidity: a problem of identity misclassification? Journal of Personality \& Social Psychology, 89(4), 552-565. doi: 10.1037/0022-3514.89.4.552

Bowles, H. R., \& Al Dabbagh, M. (2011). Status constraints in negotiation: a study of global-local biculturals in the Arab Gulf. Cambridge, MA: Harvard Kennedy School.

Bowles, H. R., \& Babcock, L. (2009). Are outside offers an answer to the compensation negotiation dilemma for women? Paper presented at the Academy of Management (Best Paper Proceedings) Chicago.

Bowles, H. R., \& Babcock, L. (2010). Relational accounts: an answer to the compensation negotiation dilemma for women. Cambridge, MA: Harvard Kennedy School.

Bowles, H. R., Babcock, L., \& Lai, L. (2007). Social incentives for gender differences in the propensity to initiate negotiations: sometimes it does hurt to ask. Organizational Behavior and Human Decision Processes, i(1), 84-103.

Bowles, H. R., Babcock, L., \& McGinn, K. L. (2005). Constraints and triggers: situational mechanics of gender in negotiation. Journal of Personality and Social Psychology, 89(6), 951-965.

Bowles, H. R., Bear, J., \& Thomason, B. (2011). At my best: gender and negotiating for self and other. Cambridge, MA: Harvard Kennedy School.

Brass, D. J. (1984). Being in the right place: a structural analysis of individual influence in an organization. Administrative Science Quarterly, 29(4), 518-539.

-_- (1985). Men's and women's networks: a study of interaction patterns and influence in an organization. Academy of Management Journal, 28(2), 327-343.

Brett, J. M., \& Stroh, L. K. (1997). Jumping ship: who benefits from an external labor market career strategy? Journal of Applied Psychology, 82(3), 331-341. 
Bryant, J. (1983). A simple rational-expectations Keynes-Type Model. Quarterly Journal of Economics, 98(3), 525-528.

Burgess, D., \& Borgida, E. (1999). Who women are, who women should be: descriptive and prescriptive gender stereotyping in sex discrimination. Psychology, Public Policy, and Law, 5(3), 665-692.

Burt, R. S. (1992). Structural Holes: The Social Structure of Competition. Cambridge, MA: Harvard University Press.

-—-. (1998). The gender of social capital. Rationality and Society, 10(1), 5-46.

Callahan-Levy, C., \& Messe, L. A. (1979). Sex differences in the allocation of pay. Journal of Personality and Social Psychology, 37(3), 433-446.

Camerer, C. F. (2003). Behavioral Game Theory: Experiments in Strategic Interaction. Princeton, NJ: Princeton University Press.

Cooper, R., Dejong, D., Forsythe, R., \& Ross, T. (1989). Communication in the battle of the sexes game: some experimental results. Rand Journal of Economics, 20, 568-587.

Crawford, V. (1991). An "evolutionary" interpretation of Van Huyck, Battalio, and Beil's experimental results on coordination. Games and Economic Behavior, 3, 25-59.

Curhan, J. R., Elfenbein, H. A., \& Kilduff, G. J. (2009). Getting off on the right foot: subjective value versus economic value in predicting longitudinal job outcomes from job offer negotiations. Journal of Applied Psychology, 94(2), 524-534.

Curhan, J. R., Elfenbein, H. A., \& Xu, H. (2006). What do people care about when they negotiate? mapping the domain of subjective value in negotiation. Journal of Personality and Social Psychology, 91(3), 493-512.

(p. 330) Dreher, G. F., \& Cox, T. H., Jr. (1996). Race, gender, and opportunity: a study of compensation attainment and the establishment of mentoring relationships. Journal of Applied Psychology, 81(3), 297-308.

Eagly, A. H. (1987). Sex Differences in Social Behavior: A Social-Role Interpretation. Hillsdale, NJ: Erlbaum.

Eagly, A. H., \& Carli, L. L. (2007). Through the Labyrinth. Boston, MA: Harvard Business School Press.

Gerhart, B., \& Rynes, S. (1991). Determinants and consequences of salary negotiations by male and female MBA graduates. Journal of Applied Psychology, 76(2), 256-262.

Glick, P., \& Fiske, S. T. (1996). The Ambivalent Sexism Inventory: differentiating hostile and benevolent sexism. Journal of Personality and Social Psychology, 70(3), 491-512. 
-_-. (2001a). An ambivalent alliance: hostile and benevolent sexism as complementary justifications for gender inequality. American Psychologist, 56(2), 109-118.

- - - (2001b). Ambivalent stereotypes as legitimizing ideologies: differentiating paternalistic and envious prejudice. In J. Jost \& B. Major (eds.), The Psychology of Legitimacy: Emerging Perspectives on Ideology, Justice and Intergroup Relations, 278306. Cambridge, UK: Cambridge University Press.

Heilman, M. E. (1983). Sex bias in work settings: the lack of fit model. In B. M. Staw \& L. I. Cummings (eds.), Research in Organizational Behavior (vol. 5, 269-298). Greenwich, CT: JAI.

Jackman, M. R. (1994). The Velvet Glove: Paternalism and Conflict in Gender, Class, and Race Relations. Berkeley: University of California Press.

Jost, J. T., \& Kay, A. C. (2005). Exposure to benevolent sexism and complementary gender stereotypes: consequences for specific and diffuse forms of system justification. Journal of Personality and Social Psychology, 88(3), 498-509. doi: 10.1037/0022-3514.88.3.498

Kilianski, S. E., \& Rudman, L. A. (1998). Wanting it both ways: do women approve of benevolent sexism? Sex Roles, 39(5-6), 333-352. doi: 10.1023/a:1018814924402

Köszegi, B. (2006). Ego utility, overconfidence, and task choice. Journal of the European Economic Association, 4(4), 673-707.

Kray, L. J., \& Gelfand, M. J. (2009). Relief versus regret: the effect of gender and negotiating norm ambiguity on reactions to having one's first offer accepted. Social Cognition, 27(3), 418-436. doi: 10.1521/soco.2009.27.3.418

Kray, L. J., \& Thompson, L. (2005). Gender stereotypes and negotiation performance: a review of theory and research. In B. M. Staw \& R. Kramer (eds.), Research in Organizational Behavior Series (Vol. 26, 103-182). Greenwich, CT: JAI Press.

O'Connor, K. M., \& Arnold, J. A. (2001). Distributive spirals: negotiation impasses and the moderating role of disputant self-efficacy. Organizational Behavior \& Human Decision Processes, 84(1), 148-176.

Phelan, J. E., Moss-Racusin, C. A., \& Rudman, L. A. (2008). Competent yet out in the cold: shifting criteria for hiring reflect backlash toward agentic women. Psychology of Women Quarterly, 32(4), 406-413. doi: 10.1111/j.1471-6402.2008.00454.x

Pinkley, R. L., \& Northcraft, G. B. (2000). Get Paid What You're Worth: The Expert Negotiator's Guide to Salary and Compensation. New York: St. Martin's Press.

Rabin, M. (1995). Moral Preferences, Moral Constraints, and Self-Serving Biases. Berkeley: University of California Press. 
Ridgeway, C. (2011). Framed by Gender: How Gender Inequality Persists in the Modern World. Oxford, UK: Oxford University Press.

(p. 331) Ridgeway, C. L., \& Bourg, C. (2004). Gender as status: an expectation states theory approach. In A. H. Eagly, A. E. Beall, \& R. J. Sternberg (eds.), The Psychology of Gender, 217-241. New York: Guliford Press.

Rudman, L. A. (1998). Self-promotion as a risk factor for women: the costs and benefits of counterstereotypical impression management. Journal of Personality and Social Psychology, 74(3), 629-645.

Rudman, L. A., \& Glick, P. (2008). The Social Psychology of Gender: How Power and Intimacy Shape Gender Relations. New York: Guilford.

Saguy, T., Tausch, N., Dovidio, J. F., \& Pratto, F. (2009). The irony of harmony: intergroup contact can produce false expectations for equality. Psychological Science, 20(1), 114121. doi: 10.1111/j.1467-9280.2008.02261.x

Scott Morton, F., Florian, Z., \& Silva-Risso, J. (2003). Consumer information and discrimination: does the internet affect the pricing of new cars to women and minorities?. Quantitative Marketing and Economics, 1(1), 65-92.

Small, D. A., Gelfand, M., Babcock, L., \& Gettman, H. (2007). Who goes to the bargaining table? the influence of gender and framing on the initiation of negotiation. Journal of Personality and Social Psychology, 93(4), 600-613.

Solnick, S. J. (2001). Gender differences in the ultimatum game. Economic Inquiry, 39(2), 189-200.

Solnick, S. J., \& Schweitzer, M. E. (1999). The influence of physical attractiveness and gender on ultimatum game decisions. Organizational Behavior and Human Decision Processes, 79(3), 199-215.

Stevens, C. K., Bavetta, A. G., \& Gist, M. E. (1993). Gender differences in the acquisition of salary negotiation skills: the role of goals, self-efficacy, and perceived control. Journal of Applied Psychology, 78(5), 723-735.

Thompson, L. (1990). Negotiation behavior and outcomes: empirical evidence and theoretical issues. Psychological Bulletin, 108(3), 515-532.

Tinsley, C. H., O’Connor, K. M., \& Sullivan, B. A. (2002). Tough guys finish last: the perils of a distributive reputation. Organizational Behavior \& Human Decision Processes, 88(2), 621-642.

Van Huyck, J., Battalio, R., \& Beil, R. (1990). Tacit coordination games, strategic uncertainty, and coordination failure. American Economic Review, 80, 234-248. 
Witt, M., \& Wood, W. (2010). Self-regulation of gendered behavior in everyday life. Sex Roles, 62(9/10), 635-646. doi: 10.1007/s11199-010-9761-y

\section{Notes:}

(1.) This subjective component most closely parallels Curhan, Elfenbein, and Xu's subjective value component of "feelings about the self." We chose to focus on this feature of their model rather than some of the other features (such as feelings about the process) because we suspected that this component was most likely to be different for men and women.

(2.) We model the impact on identity as not being affected by what other women do while the reputation costs do depend on what other women do. If other women in the environment negotiate and so does the woman, she will not incur a reputation cost but she may still feel worse about herself. We believe this is realistic because reputation effects are likely to be strongly influenced by local norms, whereas feeling about the self are influenced by global stereotypes about womanhood (their idealized feminine selfimage).

(3.) Notice that we have modeled the decision to negotiate as maximizing the individual's welfare. We have not considered the welfare of the employer or other employees. As a result, what is individually optimal may not be socially optimal.

(4.) This game is easily generalizable to more than two women. In this case, the value of $\varphi_{w}$ might depend on what the majority of women do, what the highest-status women do, or some similar summary measure.

\section{Linda Babcock}

Linda Babcock is James M. Walton Professor of Economics at the Heinz College of Carnegie Mellon University. She is the founder and faculty director of the Program for Research and Outreach on Gender Equity in Society (PROGRESS) and the coauthor of Women Don't Ask: Negotiation and the Gender Divide.

\section{Hannah Riley Bowles}

Hannah Riley Bowles is Associate Professor of public policy at the Harvard University's John F. Kennedy School of Government and the faculty director of Women and Power, the Kennedy School's executive program for women leaders from the public, private, and nonprofit sectors. Her work focuses on gender differences in a wide variety of organizational settings.

\section{Julia Bear}


Julia Bear is a postdoctoral scholar in industrial engineering and management at the Technion-Israel Institute of Technology. Her research focuses on gender roles and negotiation behavior.

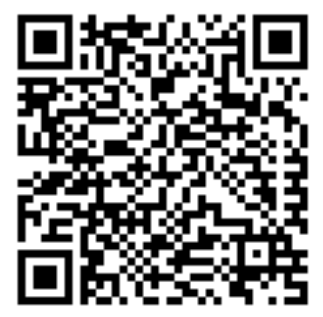

